\title{
Oesophageal intramural pseudodiverticulosis
}

\author{
SABARATNAM SABANATHAN, FAYEK D SALAMA, WILLIAM E MORGAN \\ From the Department of Thoracic Surgery, City Hospital, Nottingham
}

ABSTRACT Twelve cases of oesophageal intramural pseudodiverticulosis are described and the findings in 85 previously reported cases are reviewed. The condition occurs in all age groups, predominantly in the sixth and seventh decades, with a slight predilection for males. The characteristic radiographic appearance is of multiple flask shaped outpouchings of $1-4 \mathrm{~mm}$ with narrow necks communicating with the oesophageal lumen. The source of the pseudodiverticula has been shown to be pathologically dilated excretory ducts of the submucous glands due to chronic submucosal inflammation. The distribution was segmental in 57 cases (59\%) and diffuse in 40 (41\%). Dysphagia is the main symptom and was found in 85 cases $(88 \%)$; 88 cases out of 97 had radiological narrowing of the oesophagus; of these, $39(44 \%)$ were in the upper oesophagus, 20 $(23 \%)$ in the middle oesophagus, and $29(33 \%)$ in the lower oesophagus. Treatment is directed towards management of the associated disorder, as the diverticula themselves rarely cause problems.

Oesophageal intramural pseudodiverticulosis is an uncommon condition characterised by multiple diverticula contained within the wall of the oesophagus and therefore not visible externally, either at operation or at necropsy. Since the original description by Mendl et al, ${ }^{1} 91$ cases have been described in published reports worldwide..$^{1-5 s}$ There has been much confusion and speculation about the aetiology and pathogenesis of this disease. The purpose of this paper is to review the available information on the condition and to present 12 cases of our own.

\section{Patients and methods}

The present study is a retrospective analysis of all patients with intramural pseudodiverticulosis diagnosed and treated at Nottingham City Hospital since 1977 and a review of all the previously reported cases. In each case we have reviewed the clinical presentation, radiographic and endoscopic appearance, biopsy, intraoesophageal $\mathrm{pH}$ and manometric studies, treatment and subsequent progress. For the review, a case originally reported by Zatzkin and co-workers ${ }^{7}$ as intramural

Address for reprint requests: Mr FD Salama, FRCS, City Hospital, Nottingham, NG5 1PB.

Accepted 14 June 1985 pseudodiverticulosis that was subsequently proved to be monilial oesophagitis ${ }^{56}$ has been excluded; also excluded are the cases reported by Bender and Haddad, ${ }^{16}$ Schatzki (addendum to Hodes et $\mathrm{al}^{6}$ ), and Minnigerode et al, ${ }^{26}$ because of lack of sufficient clinical and/or radiological data.

\section{Results}

\section{PRESENT SERIES (TABLE 1)}

\section{Clinical features}

In our series of 12 patients there were eight women and four men, ranging in age from 35 to 84 years (mean 60.9 years). All the patients presented with dysphagia which had been present for one month to 14 years (mean 41.6 months). All 12 had strictures (that is, fibrous stenosis of the oesophagus), of which five were in the lower third, four in the middle third, and three in the upper third of the oesophagus. Associated conditions included sliding hiatal hernia in nine patients, sarcoidosis in one, and diabetes mellitus in another patient.

\section{pH monitoring}

All patients were studied by intraoesophageal $\mathrm{pH}$ monitoring for periods of up to 18 hours. Pathological acid reflux was considered to occur whenever the $\mathrm{pH}$ in the lower oesophagus decreased to less than 4 for more than 30 minutes. Of the 12 patients, seven had had eight episodes of acid reflux and the remaining five had had more than 10 such episodes. 
Table 1 Details of the 12 patients

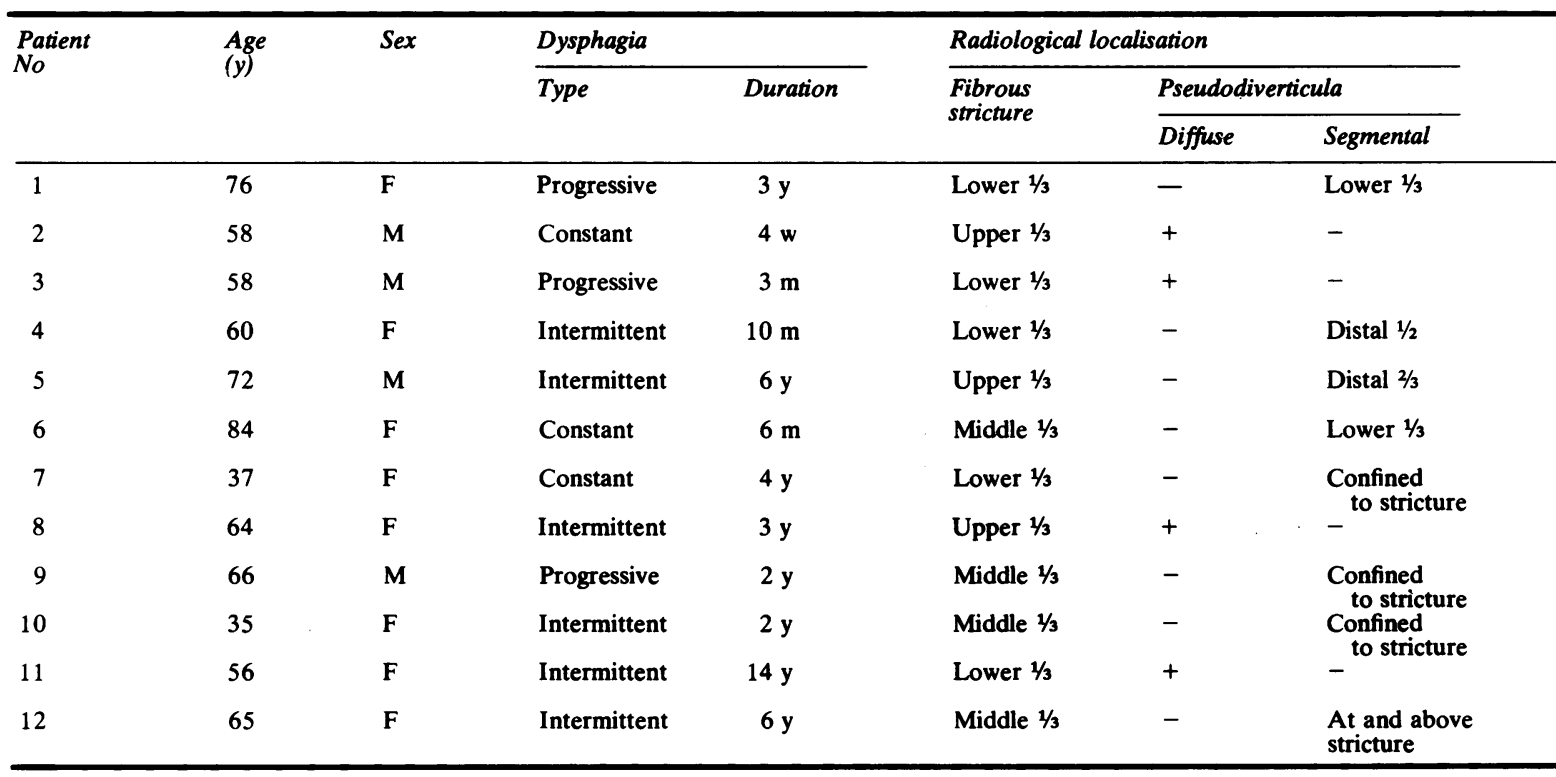

Oesophageal manometry

Oesophageal manometry was performed in four patients by a standard station pull through technique with a triple lumen catheter. This showed synchronous normal amplitude activity in the body of the oesophagus in three and high amplitude synchronous activity in one.

\section{Endoscopy and biopsy}

At oesophagoscopic examination nine patients had oesophagitis and three had Barrett's mucosa. Ostia of the diverticula were not seen in any of the 12 cases. Ten of the 12 patients had biopsies, which showed oesophagitis in seven and Barrett's epithelium in three.

\section{Treatment and progress}

Dilatation and antireflux medication in five, antireflux surgery in six, and oesophagectomy in one were the treatments used successfully in our series of patients. All but one of the patients have been followed up for periods ranging from five months to five years. One patient died of unrelated acute renal failure four years after diagnosis. Six patients who

Table 2 Results of treatment in published cases (including the present series)

\begin{tabular}{|c|c|c|c|c|c|}
\hline Treatment & $\begin{array}{l}\text { Good } \\
\text { result }\end{array}$ & $\begin{array}{l}\text { Some } \\
\text { benefit }\end{array}$ & Failure & $\begin{array}{l}\text { Results } \\
\text { not } \\
\text { stated }\end{array}$ & Total \\
\hline $\begin{array}{l}\text { Oesophageal dilatation } \\
\text { Antifungal medication } \\
\text { Antirefux medication } \\
\text { Antireflux surgery } \\
\text { Oesophagoscopy only } \\
\text { Resection or bypass of stricture } \\
\text { Spontaneous improvement } \\
\text { Division of oesophageal band } \\
\text { Extended oesophagomyotomy } \\
\text { Other treatment (antibiotics etc) } \\
\text { No treatment given } \\
\text { Refused treatment } \\
\text { Treatment method not stated } \\
\text { Total }\end{array}$ & $\begin{array}{r}29 \\
5 \\
12 \\
7 \\
7 \\
5 \\
2 \\
1 \\
1 \\
0\end{array}$ & $\begin{array}{l}6 \\
0 \\
1 \\
0 \\
0 \\
0 \\
0 \\
0 \\
0 \\
0\end{array}$ & $\begin{array}{l}3 \\
0 \\
1 \\
0 \\
0 \\
0 \\
0 \\
0 \\
0 \\
1\end{array}$ & $\begin{array}{l}2 \\
1 \\
0 \\
0 \\
0 \\
0 \\
0 \\
0 \\
0 \\
0\end{array}$ & $\begin{array}{r}40 \\
6 \\
14 \\
7 \\
7 \\
5 \\
5 \\
2 \\
1 \\
1 \\
1 \\
12 \\
2 \\
8 \\
106\end{array}$ \\
\hline $\begin{array}{l}\text { Combined treatment } \\
\text { Dilatation and antireflux medication } \\
\text { Dilatation and antifungal medication } \\
\text { Antifungal and antireflux medication } \\
\text { Total }\end{array}$ & $\begin{array}{l}6 \\
1 \\
1 \\
8\end{array}$ & $\begin{array}{l}1 \\
0 \\
0 \\
1\end{array}$ & $\begin{array}{l}0 \\
0 \\
0 \\
0\end{array}$ & $\begin{array}{l}0 \\
0 \\
0 \\
0\end{array}$ & $\begin{array}{l}7 \\
1 \\
1 \\
9\end{array}$ \\
\hline
\end{tabular}




\begin{tabular}{|c|c|c|c|}
\hline $\begin{array}{l}\text { Oesophagitis } \\
\text { lower } 2 / 3\end{array}$ & $\begin{array}{l}\text { Dilatation and antireflux } \\
\text { medication }\end{array}$ & Well & $\begin{array}{l}\text { Died } 4 \text { y later of acute renal } \\
\text { failure }\end{array}$ \\
\hline $\begin{array}{l}\text { Oesophagitis entire } \\
\text { length }\end{array}$ & $\begin{array}{l}\text { Dilatation and antireflux } \\
\text { medication }\end{array}$ & Well & $\begin{array}{l}\text { No change in diverticula } \\
\text { after } 5 \mathrm{y}\end{array}$ \\
\hline $\begin{array}{l}\text { Oesophagitis entire } \\
\text { length }\end{array}$ & $\begin{array}{l}\text { Dilatation and antireflux } \\
\text { medication }\end{array}$ & Well & $\begin{array}{l}\text { Lost to follow up } \\
\text { after } 2 \text { y }\end{array}$ \\
\hline Oesophagitis lower $1 / 2$ & $\begin{array}{l}\text { Belsey Mk IV antireflux } \\
\text { surgery }\end{array}$ & Well & $\begin{array}{l}\text { No change in diverticula } \\
\text { at } 4 \mathrm{y}\end{array}$ \\
\hline $\begin{array}{l}\text { Barrett's oesophagus } \\
\text { lower } 2 / 3\end{array}$ & $\begin{array}{l}\text { Dilatation and antireflux } \\
\text { medication }\end{array}$ & Well & $\begin{array}{l}\text { No follow up } \\
\text { barium study }\end{array}$ \\
\hline $\begin{array}{l}\text { Barrett's oesophagus } \\
\text { below stricture }\end{array}$ & $\begin{array}{l}\text { Dilatation and antireflux } \\
\text { medication }\end{array}$ & Well & $\begin{array}{l}\text { No change in diverticula } \\
\text { after } 4 \mathrm{y}\end{array}$ \\
\hline $\begin{array}{l}\text { Barrett's oesophagus } \\
\text { below stricture }\end{array}$ & $\begin{array}{l}\text { Oesophagectomy and } \\
\text { oesophagogastrostomy }\end{array}$ & Well & $\begin{array}{l}\text { No follow up barium } \\
\text { study }\end{array}$ \\
\hline $\begin{array}{l}\text { Oesophagitis entire } \\
\text { length }\end{array}$ & $\begin{array}{l}\text { Total fundoplication, } \\
\text { gastroplasty }\end{array}$ & Well & $\begin{array}{l}\text { No change in diverticula } \\
\text { after } 3 \mathrm{~m}\end{array}$ \\
\hline Oesophagitis lower $2 / 3$ & $\begin{array}{l}\text { Total fundoplication, } \\
\text { gastroplasty }\end{array}$ & Well & $\begin{array}{l}\text { No follow up barium } \\
\text { study }\end{array}$ \\
\hline Oesophagitis lower $1 / 3$ & Nissen fundoplication & Well & $\begin{array}{l}\text { No follow up barium } \\
\text { study }\end{array}$ \\
\hline Oesophagitis lower $2 / 3$ & $\begin{array}{l}\text { Total fundoplication, } \\
\text { gastroplasty }\end{array}$ & Well & $\begin{array}{l}\text { No change in diverticula } \\
\text { after } 1 \mathrm{y} \text {. }\end{array}$ \\
\hline $\begin{array}{l}\text { Extensive oesophagitis } \\
\text { lower } 1 / 3\end{array}$ & $\begin{array}{l}\text { Total fundoplication, } \\
\text { gastroplasty }\end{array}$ & Well & $\begin{array}{l}\text { No change in diverticula } \\
\text { after } 5 \mathrm{~m}\end{array}$ \\
\hline
\end{tabular}

had a follow up barium swallow examination showed no change in either the number or the size of diverticula for up to five years.

\section{REVIEW OF PUBLISHED CASES (TABLE 2) Clinical features}

In the total series of 97 reported cases (which include our own 12 cases) there were 56 men ( $58 \%$ ) and 41 women $(42 \%)$. The ages ranged from 8 months to 86 years (mean 53.5 years). The incidence related to sex and age at presentation is shown in figure 1 . Most cases (54\%) were diagnosed in the sixth and seventh decades. No racial predilection exists.

Dysphagia, predominantly for solids, was present in $88 \%$ of patients. Twelve patients were symptom free and the pseudodiverticulosis was discovered incidentally. Only three cases presented with acute dysphagia, the remaining cases having a chronic course. Dysphagia was either constant (22 cases), intermittent ( 25 cases), or progressive (30 cases). Episodes of acute bolus obstruction, in most instances resolving spontaneously, occurred in 15 of 97 cases. The mean duration of symptoms was 60.5 months (range two days to 26 years).

Twenty cases $(21 \%)$ were associated with a hiatal hernia. Evidnce of free gastro-oesophageal reflux was obtained in 29 cases, in 12 by intraoesophageal $\mathrm{pH}$ monitoring and in the rest during barium swallow examination. Other accompanying diseases were diabetes mellitus in 15 cases (15.5\%) and chronic alcoholism in $15(15.5 \%)$. Lye ingestion, Plummer-Vinson syndrome, carcinoma of the oesophagus, and bronchial asthma requiring steroid treatment were each encountered twice. Pulmonary tuberculosis, Wegener's granulomatosis, pneumoconiosis, immune deficiency, Gram negative sepsis, pharyngeal diverticulum, and ovarian carcinomatosis were present in one case each. One case was complicated by a fistula into the mediastinum with resulting fatal mediastinitis. ${ }^{27}$

\section{Radiological features}

The barium swallow findings in this condition are characteristic. Many flask or collar stud shaped outpouchings measuring 1-4 $\mathrm{mm}$ in length are seen. They usually project at right angles to the lumen and communicate with it through narrow necked openings. Computed tomography has shown considerable thickening of the oesophageal wall, diffuse irregularity of the oesophageal lumen, and intramural gas collections. ${ }^{52}$ The distribution of the pseudodiverticula was segmental in 57 cases and diffuse (fig 2) in 40 . Of those cases with a segmental distribution, 21 had the upper third affected, 16 the middle third, and 26 the lower third.

Radiological narrowing of the oesophagus was present in $91 \%$ of cases $-44 \%$ in the upper third, $23 \%$ in the middle third, and $33 \%$ in the distal third. A cervical web was found in five cases. Pseudodiverticula were limited to the narrowed segment in 24 cases (fig 3 ). In the other cases with segmental 


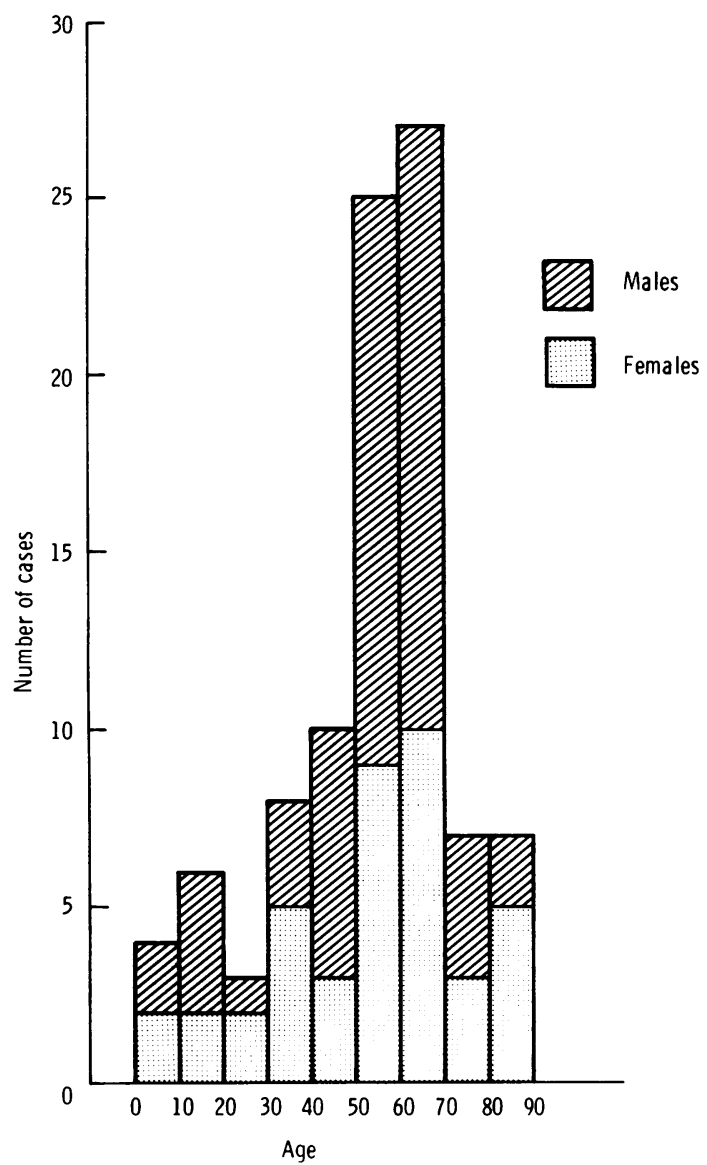

Fig 1 Incidence of oesophageal intramural pseudodiverticulosis in relation to sex and age at the time of diagnosis.

distribution they were found above the oesophageal narrowing in seven, at the oesophageal narrowing and above in 13 (fig 4), below the oesophageal narrowing in five (fig 5), and at the oesophageal narrowing and below in eight instances. Evidence of disordered motility, manifested by irregular tonic simultaneous contractions (six cases), tertiary contractions (five cases), aperistalsis (five cases), impaired peristalsis (three cases), lack of distensibility (two cases), exaggerated normal peristalsis (one case), and a non-specific motility defect (seven cases), was present in 29 of the total of 97 cases. Motility was described as normal in two patients.

\section{Manometry}

Despite the fact that oesophageal dysmotility was suggested in the first description of the condition,'

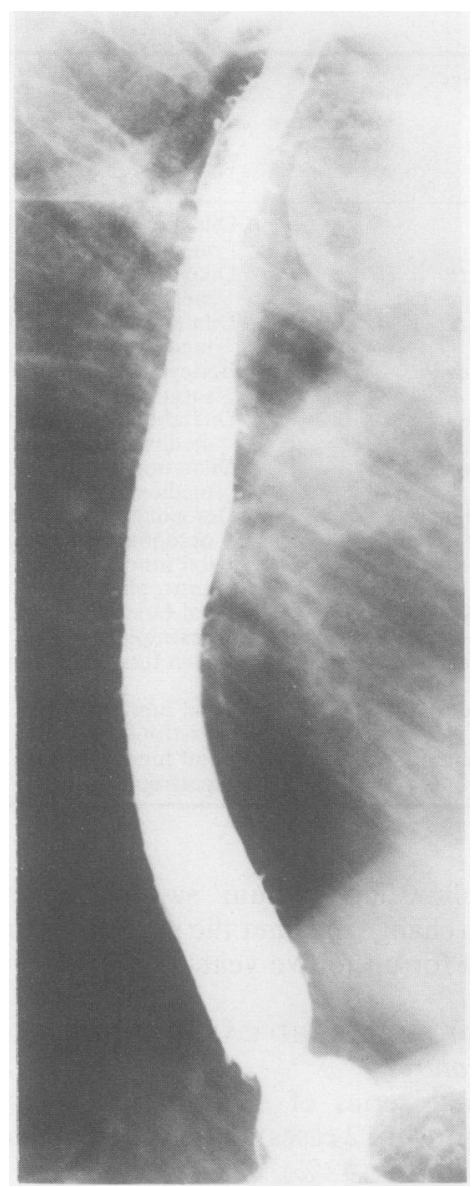

Fig 2 Barium swallow showing diffuse intramural pseudodiverticulosis: case 8.

only 19 patients have had manometric studies, 15 being shown to have either generalised or local abnormalities. Localised aperistalsis confined to the area of oesophageal narrowing was seen in two cases, complete aperistalsis in three, decreased amplitude normal peristalsis in two, primary diffuse oesophageal spasm in one, and high amplitude peristaltic contractions in one. Synchronous tertiary contractions with normal amplitude were seen in five cases (fig 6) and with high amplitude in one case.

\section{Endoscopy}

Endoscopy was performed in 84 cases. This showed the orifices of the pseudodiverticula in 21 cases (25\%), changes of oesophagitis in $57(68 \%)$, Barrett's mucosa in five (6\%), and endoscopic oesophageal narrowing in $57(68 \%)$. In 22 patients 


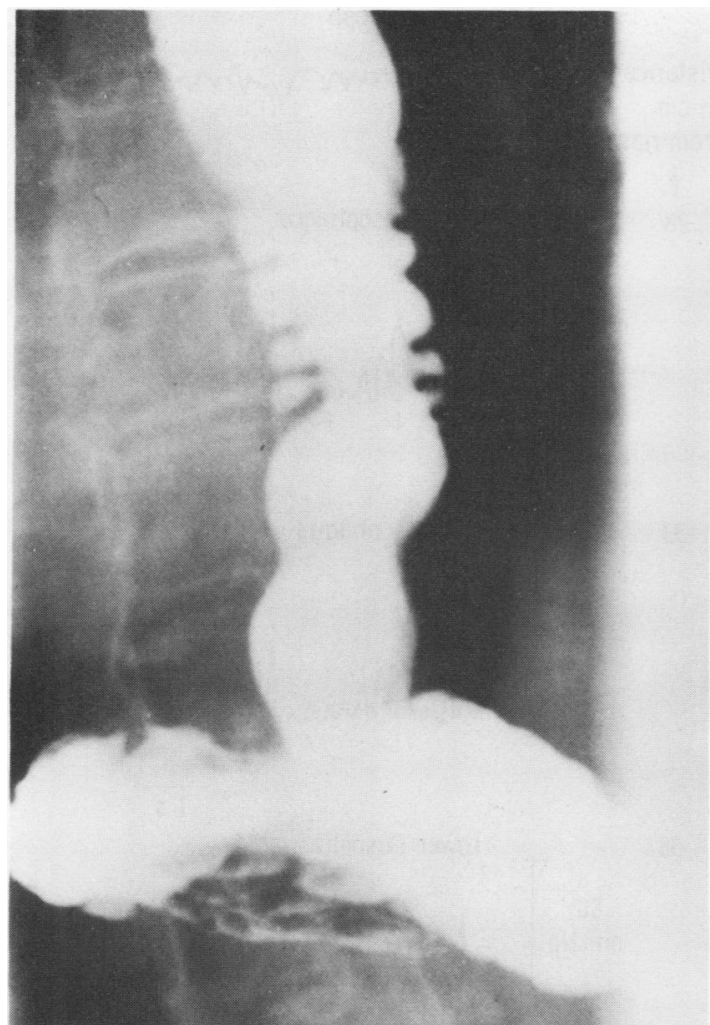

Fig 3 Intramural pseudodiverticulosis within an area of stricture: case 10.

(27\%) the oesophageal mucosa was described as normal. The ostia of the outpouchings were described as pinhead sized, yellow white mucosal elevations with a thick, creamy liquid expressible from a central opening, ${ }^{2}$ as multiple punctate openings with ${ }^{21}$ or without ${ }^{24} 30$ expressible fluid, or as multiple red orifices protruding from the oesophageal lumen. ${ }^{3 y}$ When visualised the mouths of the diverticula were found to be distributed in a linear fashion along the wall between the normal oesophageal folds, a location corresponding to that of normal oesophageal glands. ${ }^{21}$ Endoscopic oesophagitis was manifested by hyperaemia, mucosal oedema, friability, erosions, or ulceration.

\section{Pathology and microbiology}

Oesophageal biopsy specimens (58 cases) or full thickness necropsy sections (seven cases) were available for examination for 65 patients. Evidence of acute or chronic inflammatory infiltrate was seen in $55(85 \%)$ of the 65 patients. Other abnormalities

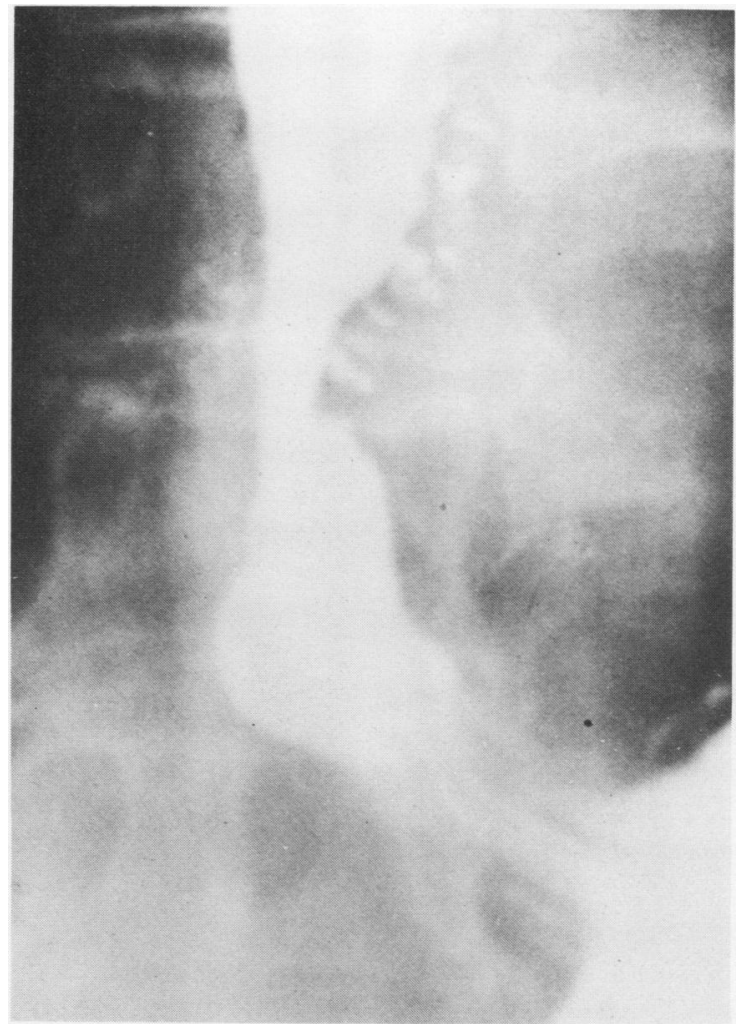

Fig 4 Barium swallow showing pseudodiverticulosis at and above stricture: case 12.

in antemortem specimens were submucosal fibrosis and Barrett's epithelium. Biopsy specimens are of limited value in detecting lesions because the pseudodiverticular formations are intramural and usually not included in the submitted specimen. Candida albicans was cultured from the oesophagus in 15 of 37 cases and biopsy specimens showed evidence of tissue invasion in five cases. Both culture and biopsy specimens were positive for Candida albicans in only two cases.

\section{Treatment and prognosis (table 2)}

Dilatation of oesophageal narrowings was performed in 40 cases and relieved symptoms completely or substantially in $35(87.5 \%)$. No direct treatment was required in at least 12 patients. Other treatments that have been used are antimycotic drugs (six cases, successful in five), hiatal hernia repair (seven cases, successful in all), antireflux medication (14 cases, successful in 12), and antibiotics (one case, unsuccessful). Two patients improved 


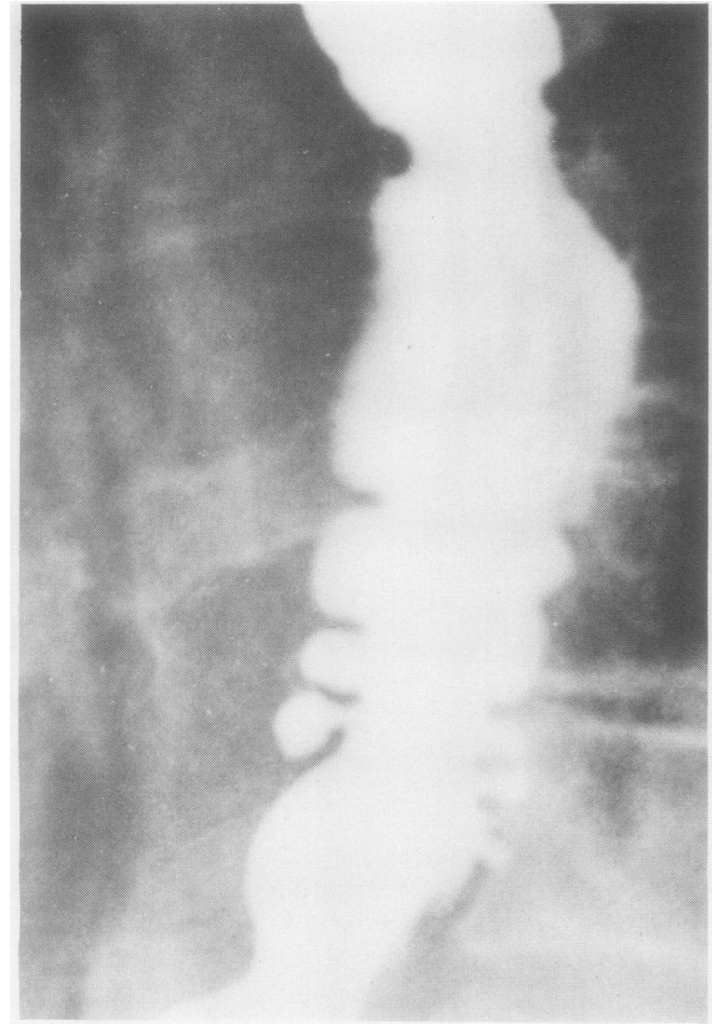

Fig 5 Intramural pseudodiverticulosis distal to stricture: case 6.

spontaneously. ${ }^{23} 38$ Among the 36 patients followed up, disappearance (seven cases) or a decrease in the number of pseudodiverticula (six cases) has occurred in $36 \%$. In 23 patients the pseudodiverticula remained unchanged in appearance for up to 16 years after treatment ${ }^{45}$ (range three months to 16 years, mean follow up 1.9 years).

The course of the disease is benign and only one fatal complication, with a fistula into the anterior mediastinum, has been reported. ${ }^{27}$

\section{Discussion}

Oesophageal intramural pseudodiverticulosis is a rare benign disorder occurring at all ages and more frequent in males. The condition usually presents with dysphagia, which typically is not severe and is usually intermittent or slowly progressive. There is a high incidence of oesophageal narrowing, usually in the upper third of the oesophagus, associated with the 1-4 mm flask shaped diverticula seen on barium

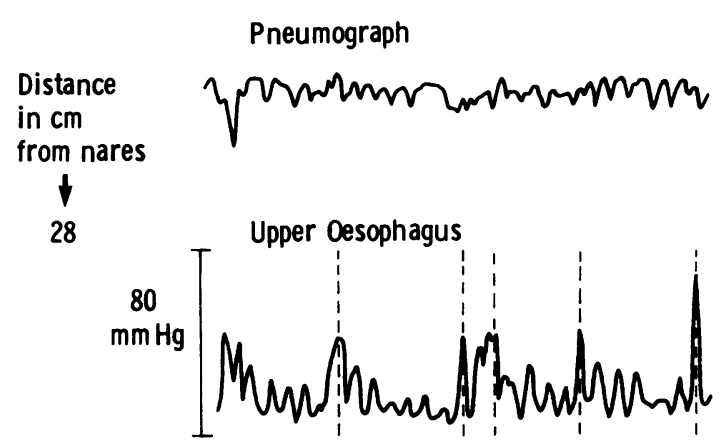

33

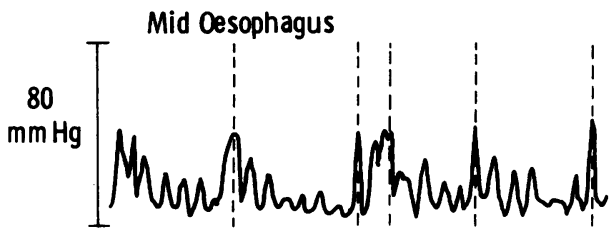

38

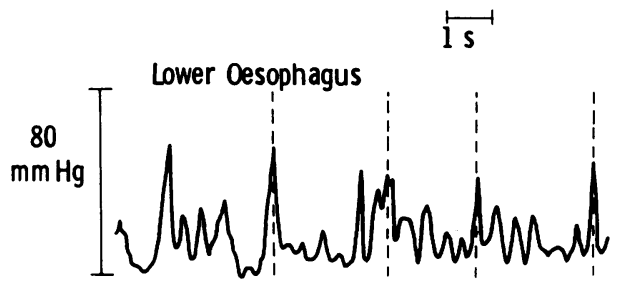

Fig 6 Oesophageal manometric tracing showing normal amplitude synchronous activity: case 9.

swallow examination. Endoscopy is not helpful in the diagnosis but shows inflammatory changes; in only a few cases are the ostia of the pseudodiverticula visible. Biopsy is not usually diagnostic as the pseudodiverticula are too deep to be included in the specimen. Radiology therefore offers the most sensitive method of diagnosis. Although the radiological appearances at a barium swallow examination are virtually pathognomonic they have been confused with monilial oesophagitis. With monilial infection, however, the typical smooth, flask shaped diverticula are not seen.

The aetiology of the pseudodiverticulosis remains speculative. In their original report Mendl et al ${ }^{1}$ proposed that the basic defect in intramural pseudodiverticulosis was a herniation of the mucosa along the pathways of blood vessels and nerves into the intramural portion of the oesophagus, due to an increase in intraluminal pressure in the oesophagus. Necropsy studies, however, have shown pseudodiverticula to be dilated pre-existing excret- 
ory ducts of the submucous glands. ${ }^{4527} 24$

Lupovitch and Tippins ${ }^{3}$ postulated a congenital or acquired adenosis predisposing to chronic inflammation, resulting in cystic dilatation and squamous metaplasia. Wightman and Wright, ${ }^{4}$ on the basis of histological examination of a postmortem case, rejected the theory of adenosis and proposed that the oesophageal gland ducts undergo squamous metaplasia in response to chronic irritation. Umlas and Sakkuja ${ }^{5}$ and Hammon et al ${ }^{19}$ studied several normal oesophagi by serial sections and observed that ducts of the oesophageal glands are normally lined by stratified squamous epithelium and therefore it is not necessary to postulate a metaplastic change. There appear to be the same number of pseudodiverticula in the pathological state as of gland duct units in the normal state; the main difference is the dilatation and surrounding inflammation. Pseudodiverticula are the result of pathological dilatation of these ducts. ${ }^{427}{ }^{24}$ Not surprisingly, since most of the gland duct units occur in the upper half of the normal oesophagus, ${ }^{19}$ pseudodiverticula are most numerous there. The aetiology of the pathological dilatation of the submucosal gland ducts to form pseudodiverticula remains controversial. Because most patients are in their sixth and seventh decades, and also because stricture formation precedes pseudodiverticulosis in some cases, ${ }^{113444}$ we believe, like most authors, that this is an acquired lesion, ${ }^{25}$ y1113-1517192027-303235363943-455254 despite the occurrence of a few cases in childhood.

Most of the evidence suggests that the initiating event is chronic inflammation-whether the cause is fungal (candidiasis), bacterial, or chemical as in gastro-oesophageal reflux - of the submucosal oesophageal glands. ${ }^{25} 9111417-192724-323536344345465254$ Obstruction of the ductal orifices by periductal inflammation or fibrosis, or both, produces dilatation of the ducts and the typical outpouchings seen on barium swallow examination. The thickening of the oesophagus seen in postmortem specimens and computed tomography scans has been shown to be due to submucosal fibrosis. ${ }^{35192724}$ Failure to demonstrate oesophagitis endoscopically in 22 cases does not exclude the possibility of oesophagitis in the absence of histological examination, because inflammatory changes in the oesophagus begin microscopically in the area of the lamina propria and only later affect the epithelial layer. ${ }^{57-54}$ Histological examination of the oesophageal mucosa will often show inflammatory changes in the submucosa even when the mucosa appears normal on endoscopic examination. ${ }^{58}$ Failure to detect inflammation in four cases could be explained if the biopsy specimens came from an area where inflammation had disappeared.
The association of Candida albicans with oesophageal intramural pseudodiverticulosis deserves further consideration. When specifically sought for Candida has been present in almost half the cases (18 of 37 patients). As it is a common inhabitant of the oropharyn $x^{60}$ it has been given an incidental rather than an aetiological role. Orringer and Sloan ${ }^{31}$ and others, ${ }^{62852}$ however, believe that chronic infection of the oesophageal submucosal glands by Candida albicans must be recognised as one cause of pseudodiverticulosis.

Oesophageal narrowing was found in most of the reported cases $(91 \%)$, with a predilection toward the cervical and upper thoracic oesophagus (44\%). It has been suggested that strictures in this disorder may result from localised peridiverticulitis. ${ }^{21}$ The absence of oesophageal narrowing in some cases, however, and the presence of pseudodiverticula distal to the oesophageal narrowing in many cases suggest that oesophageal narrowing is also a secondary consequence of the diffuse oesophagitis, as is the commonly found abnormal motor activity. Chronic oesophagitis is a relatively common condition while pseudodiverticulosis is rare. Conceivably failure to detect pseudodiverticula could result from blockage of the ducts by mucoid and inflammatory material, preventing their filling with barium. ${ }^{34} 4454$ The work of Hammon et al, ${ }^{14}$ who studied oesophagi obtained at routine postmortem examination, supports this view.

All the 12 patients in our series proved to have gastro-oesophageal reflux; similar findings have been published previously. 11172225283234434446 This suggests that intramural pseudodiverticulosis of the oesophagus may represent yet another complication of reflux oesophagitis. Intramural pseudodiverticulosis of the oesophagus seems to have no clinical importance as such, but is an indication that "something is amiss" in the oesophagus. Treatment is directed at relieving oesophageal obstruction, if any, and dealing with the underlying inflammatory condition. The results of long follow up in many cases $^{2} 61823254445$ indicate that the condition may remain relatively stable for long periods.

\section{References}

1 Mendl K, McKay JM, Tanner $\mathrm{CH}$. Intramural diverticulosis of the oesophagus and Rokitansky-Aschoff sinuses in the gall-bladder. Br J Radiol 1960;33:496501.

2 Boyd RM, Bogoch A, Greig JH, Trites EW. Esophageal intramural pseudodiverticulosis. Radiology 1974; 113:267-70.

3 Lupovitch A, Tippins R. Esophageal intramural pseudodiverticulosis: a disease of adnexal glands. Radiology 1974;113:271-2. 
4 Wightman AJA, Wright EA. Intramural oesophageal diverticulosis: a correlation of radiological and pathological findings. $\mathrm{Br} J$ Radiol 1974;47:496-8.

5 Umlas J, Sakhuja R. The pathology of oesophageal intramural pseudodiverticulosis. Am J Clin Pathol 1976;65:314-20.

6 Hodes PJ, Atkins JP, Hodes BL. Esophageal intramural diverticulosis. Am J Roentgenol 1966; 96:410-3

7 Zatzkin HR, Green S, Lavine JJ. Esophageal intramural diverticulosis. Radiology 1968;90:1193-4.

8 Culver GJ, Chaudhari KR. Intramural esophageal diverticulosis. Am J Roentgenol 1967;99:210-11.

9 Troupin RH. Intramural esophageal diverticulosis and moniliasis. Am J Roentgenol 1968;104:613-6.

10 Creely JJ, Trail ML. Intramural diverticulosis of the esophagus. South Med J 1970;63:1257-60.

11 Weller MH, Lutzker SA. Intramural diverticulosis of the esophagus associated with postoperative hiatal hernia, alkaline esophagitis and esophageal stricture. Radiology 1971;97:373-7.

12 Cramer KR. Intramural diverticulosis of the oesophagus. Br J Radiol 1972;45:857-9.

13 Weller MH. Intramural diverticulosis of the esophagus: report of a case in a child. $J$ Pediatrics 1972;80:281-5.

14 Lane JW. Intramural esophageal diverticulosis: a case report. Journal of the Arkansas Medical Society 1972;69:87-90.

15 Sperling HV, D' Altoria RA. Intramural diverticulosis of the esophagus. Digest Dis 1973;18:978-82.

16 Bender MD, Haddad JK. Disappearance of multiple esophageal diverticula following treatment of esophagitis: serial endoscopic, manometric, and radiologic observations. Gastrointestinal Endoscopy 1973;20:19-22.

17 Mendl K, Montgomery RD, Stephenson SF. Segmental intramural diverticulosis associated with and confined to a spastic area of muscular hypertrophy in a columnar lined oesophagus. Clin Radiol 1973;24:440-4.

18 Beauchanp JM, Nice CM, Belanger MA, Neitzschman HR. Esophageal Intramural pseudodiverticulosis. Radiology 1974;113:273-76.

19 Hammon JW jun, Rice RP, Postlethwait RW, Young WG jun. Esophageal Intramural Diverticulosis: a clinical pathological survey. Ann Thorac Surg 1974; 17:260-7.

20 Hupscher DN. Intramural diverticulosis of the oesophagus. Radiol Clin Biol 1974;43:144-54.

21 Graham DY, Goyal RK, Sparkman J, Cagan ME, Pogonowska MJ. Diffuse intramural esophageal diverticulosis. Gastroenterology 1975;68:781-5.

22 Schwegler N, Faust H. Radiologische aspekte der intramuralen oesophagus-divertikulose. Fortschr Roentgenstr 1975;122:151-5.

23 Montgomery RD, Mendl K, Stephenson SF. Intramural diverticulosis of the oesophagus. Thorax 1975;30:278-84.

24 Fee BE, Dvorak AD. Intramural pseudodiverticulosis of the esophagus. Nebraska Med Jnl 1976;Jan:9-13.

25 Redlich FH. Zur intramuralen Osophagusdivertikulose. Radiol Diagn (Berlin) 1976;17:217-24.

26 Minnigerode B, Bartholome W, Kupper R. The endoscopic picture of the intramural oesophageal diverticulosis. Endoscopy 1977;9:203-7.

27 Rahlf G, Wilbert L, Lankisch PG, Ruttemann-U.
Intramural esophageal diverticulosis. Acta Hepatogastroenterol 1977;24:110-5.

28 Shapiro MJ, Sloan WC. Intramural pseudodiverticulosis of the esophagus. Ann Otol 1977;86:594-7.

29 Fromkes J, Thomas FB, Mekhjian H, Caldwell JH, Johnson JC. Esophageal intramural pseudodiverticulosis. Digest Dis 1977;22:690-700.

30 Castillo S, Aburashed A, Kimmelman J, Alexander LC. Diffuse intramural esophageal pseudodiverticulosis: new cases and review. Gastroenterology 1977;72:541-5.

31 Orringer MB, Sloan H. Monilial esophagitis: an increasingly frequent cause of esophageal stenosis? Ann Thorac Surg 1978;26:364-74.

32 Braun P, Nussle D, Roy CC, Cuendet A. Intramural diverticulosis of the esophagus in an eight-year-old boy. Pediatr Radiol 1978;6:235-7.

33 Van Overbeek JJM, Edens ET, Gokemeijer JDM, Broker FHL. Intramural diverticulosis of the esophagus. Laryngoscope 1978;88:1671-9.

34 Libert M, De Toeuf J, Andre P. Pseudo-diverticulose intramurale de L'oesophage. Acta Gastroenterol Belg 1978;41:162-8.

35 Hermanutz VKD, Lindstaedt $H$, Miederer SE. Intramurale Pseudodivertikulose des Osophagus. Fortschr Rontgenstr 1978;128:115-8.

36 Lammer J, Biffl H. Die oesophageale intramurale Pseudodivertikulose. Radiologe 1979;19:445-50.

37 Farack VUM, Kinnear DG, Jabbari M. Die intramurale Pseudodivertikulose des Ösophagus-eine primär radiologische. Diagnose Fortschr Rontgenstr 1979; 130:508-9.

38 Starinsky R, Manor A, Pajewsky M, Varsano D. Intramural esophageal diverticulosis in an infant. Israel J Med Sci 1980;16:604-6.

39 Muhletaler CA, Lams PM, Johnson AC. Occurence of oesophageal intramural pseudodiverticulosis in patients with pre-existing benign oesophageal stricture. Br J Radiology 1980;53:299-303.

40 Lübke HJ, Bloch R. Die intramurale Divertikulose des Ösophagus. Leber Magen Darm 1981;11:139-43.

41 Delgoffe C, Regent D, Stines J, Humbert B, Treheux A. La Pseudo-diverticulose intramurale de l'oesophage: aspects radiologiques à propos de 2 cas. $J$ Radiol 1981;12:635-8.

42 Broeckaert I, Lecocq E. Pseudo-diverticulose intramurale de L'oesophage. Gastroenterol Clin Biol 1981;5:522-6.

43 Cho SR, Sanders MM, Turner MA, Liu CI, Kipreos BE. Esophageal intramural pseudodiverticulosis. Gastointestinal Radiology 1981;6:9-16.

44 Brühlmann WF, Zollikofer CL, Maranta E, et al. Intramural pseudodiverticulosis of the esophagus: report of seven cases and literature review. Gastrointest Radiol 1981;6:199-208.

45 Peters ME, Crummy AB, Wojtowycz MM, Toussaint JB. Intramural esophageal pseudodiverticulosis: a report in a child with a sixteen-year follow up. Pediatr Radiol 1982;12:262-3.

46 Greenstein R, Shah HV. Esophageal intramural pseudodiverticulosis. Ill Med J 1982;162:32-3.

47 Cantor DS, Riley TL. Intramural pseudodiverticulosis of the esophagus. Am J Gastroenterol 1982;77:454-6.

48 Walter K. Ungewöhnliche Divertikel-intramurale Oesophagusdivertikulose, intraduodenale Divertikel: zwei Fallberichte. Radiologe 1983;23:551-2. 
49 Bavastro VP, Gerlach A. Die intramurale Divertikulose des Öesophagus. Z Gastroenterol 1983;21:159-63.

50 Schmutz G, Zeller C, Doffoel M, Kempf F. Une cause rare de blocage alimentaire: la pseudo-diverticulose intra-murale de l'oesophage. Presse Méd 1983;12: 641-2.

51 Murney RG, Linne JH, Curtis J. High-amplitude peristalitic contractions in a patient with esophageal intramural pseudodiverticulosis. Digest Dis Sci 1983;28:843-7.

52 Pearlberg JL, Sandler MA, Madrazo BL. Computed tomographic features of esophageal intramural pseudodiverticulosis. Radiology 1983;147:189-90.

53 Gerlach VA, Bavastro P, Reichardt W. Beitrag zur Röntgenmorphologie der intramuralen Pseudodivertikulose des Ösophagus. Fortschr Röntgenstr 1984; 140:281-3.

54 Santos GH, Baker SR, Frater RWM. Intramural pseudodiverticulosis of the esophagus. J Thorac Car- diovasc Surg 1984;87:120-3.

55 Cronen PW. Diffuse esophageal intramural pseudodiverticulosis. South Med J 1984;77:771-2.

56 Smulewicz IJ, Dorfman J. Esophageal intramural diverticulosis: a re-evaluation. Radiology 1971;101: 527-9.

57 Henderson RD, Pearson FG. Preoperative assessment of oesophageal pathology. J Thorac Cardiovasc Surg 1976;72:512-7.

58 Svoboda AC, Knauer M, Gamble CN, Sommers SC, Monroe LS. Problems in the early diagnosis of peptic oesophagitis. Gastrointestinal Endoscopy 1967;13: 14-7.

59 Ballem CM, Fletcher HW, McKenna RD. The diagnosis of oesophagitis. Am J Digest Dis 1960;5:88-93.

60 Cohen R, Roth FJ, Delgado E, Ahearn DG, Kalser MH. Fungal flora of the normal human small and large intestine. $N$ Engl J Med 1969;280:638-41. 